\title{
Optimize Thermal Management And Experiment Of Lifepo4 Battery Pack For Hybrid Electrical Vehicle
}

\author{
Abdul Muchlis ${ }^{1 *}$, Moh. Yamin ${ }^{2}$ \\ ${ }^{1,2}$ Fakultas Teknologi Industri Universitas Gunadarma, Jawa Barat Indonesia \\ ${ }^{*}$ Corresponding author: \\ Email: muchlis07@staff.gunadarma.ac.id
}

\begin{abstract}
.
Hybrid Electric Vehicles (HEV) combines the benefits of gasoline engines and electric motors which can be configured for improving fuel efficiency. Lithium Iron Phosphate (LiFePO4) Phosphate based technology possesses superior thermal and chemical stability which provides better safety characteristics than those of Lithium-ion technology made with other cathode materials. This research conducted by two methods, methods of part 1 is a comparison of the results with the thermal management simulation and experiment, part 2 is a method of optimizing the thermal management for battery pack by using solidwork software. When the fan is on, the forced air flow over the cells removes some of the generated heat. Results of method part 1 is simulation more heat than experiment in the amount of $0.11 \%-1.56 \%$. The results of the method part 2 is simulated using the fan 4 fan with a speed of $415 \mathrm{rad} / \mathrm{s}$ and battery gap 30mm most efficient compared with 4 fans the other, while the simulation using 6 fan, fan speed $415 \mathrm{rad} / \mathrm{s}$ and battery gap $30 \mathrm{~mm}$ most efficient for all.
\end{abstract}

Keywords: Battery, Simulation, Temperature

\section{INTRODUCTION}

At industry world incesstanly to do research for energy alternative. In special to motor vehicle that use fossil fuel. It is to produce emission pollution, so that goverment and indutry automobile to cooperate for to obtain solution this problem, exactly to reduce emission pollution. If project to success to appoint to reduce consumtion fossil fuel. Many method for reduce consumtion fossil fuel and alternative power, either one is combination internal combustion engine (ICE) or conventional engine and electrical vehicle.This is to produce power and energy kinetic. The power to continue at wheel. The electrical vehicle have advantage, either one not produce emission air when energy electric to change energy kinetic. Because temperature battery to change high. It is to reduce performa in electrical vehicle. So, it is need management battery for control temperature battery. Battery is cooled by fan, that function is control temperature battery.Problem in the research is management temperature in battery for hybrid electrical vehicle(HEV). This is very important to battery perform. This research use fan, this fan to produce wind force to control battery temperature HEVs. Research Objective is analyze comparison solidwork and experiment and margin error for 1 batttery at charge and discharge situation and effect battery gap, fan velocity and numbers fans with cooling system.

\section{METHODS}

This research presents thermal management of battery packs in hybrid electric vehicle (HEVs) to maximize pack performance. A battery pack type on this research is LiFePO4 HP-PW-100AH hybrid vehicle system in Toyota Soluna. Configurations system battery is series, capacity battery is 3.65 voltage of single cells. This research was conducted by comparing simulations and experiments on single batteries, not only that this 
study is also to seek optimization gap, numbers fan and fan speed in the battery pack cooling system with a number of batteries 15 pieces.

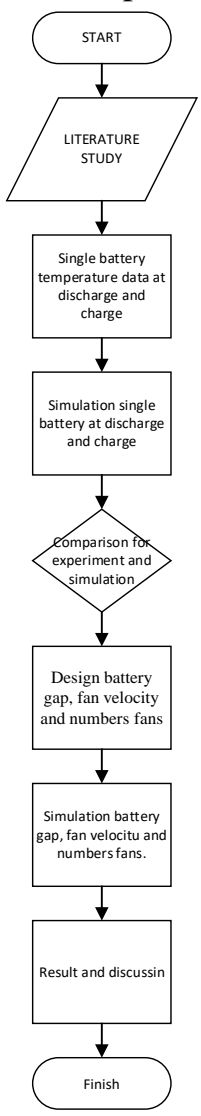

Fig 1. Flowchart

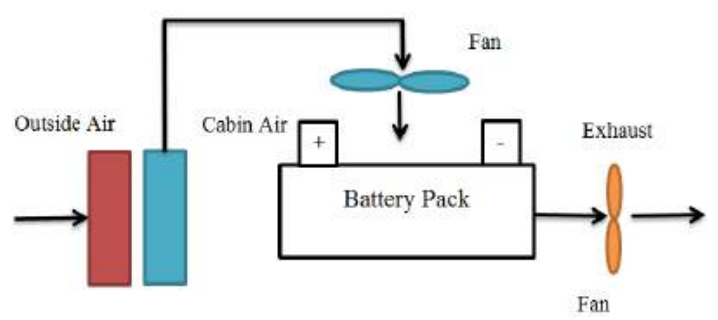

Fig 2. Cooling system thermal management

Experiments conducted on three conditions, namely battery charging $45^{\circ} \mathrm{C}, 50^{\circ} \mathrm{C}$ and $60^{\circ} \mathrm{C}$ discharging. The observation point there are 36 points on the surface of the battery, which consists of 6 columns and 6 rows. Just as the figure below:
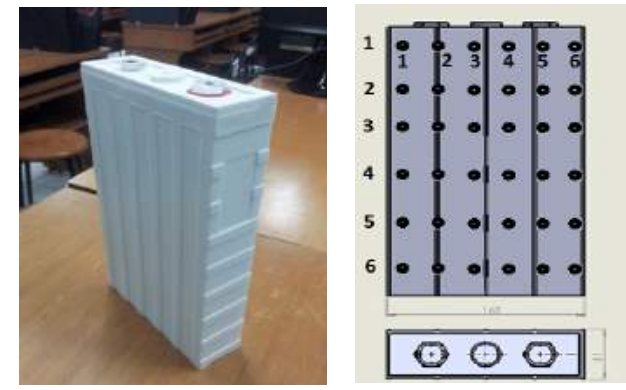

Fig 3. Observation point

Table 1. Battery specifications

\begin{tabular}{ll}
\hline Spesifikasi Battery & HP-PW-100AH \\
\hline Charge Voltage & $3.65 \mathrm{~V}$ \\
Discharge Voltage & $3.2 \mathrm{~V}$ \\
Nominal Capacity & $100 \mathrm{AH}$ \\
Dimension $(\mathrm{L} * \mathrm{~W} * \mathrm{H})(\mathrm{mm})$ & $163 \times 51 \times 278$ \\
Weight & $3.4 \mathrm{~kg}$
\end{tabular}




\begin{tabular}{cc} 
Temperature Charging & $0-45^{\circ} \mathrm{C}$ \\
Temperature Discharging & $0-60^{\circ} \mathrm{C}$ \\
\hline Optimation Battery Gap
\end{tabular}

To search for the optimization of the battery cooling system, performed with distinction at the gap batteries, that is $10 \mathrm{~mm}, 20 \mathrm{~mm}$ and $30 \mathrm{~mm}$

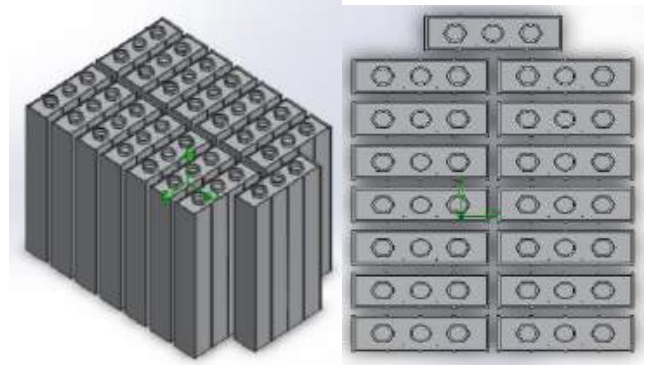

Fig 2. Battery gap $10 \mathrm{~mm}$

\section{Optimize fan arrangement}

Cooling by increasing the number of fans to seek optimization of the number of fan with battery gap.
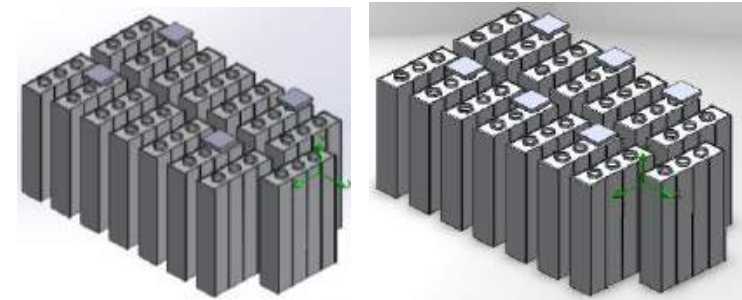

Fig 3. Fan arrangement 4 and 6 pieces

\section{Optimize Fan Speed}

Fan speed to seek optimization of cooling the battery gap and the number of fans. The simulation used two types of fans, that is:

1. Axial, comoir Rotron, AC, FA/B-50Hz with Rpm $296.45129 \mathrm{rad} / \mathrm{s}$.

2. Axial, comoir Rotron,DC, FNxxK3 with Rpm $415.21384 \mathrm{rad} / \mathrm{s}$.

\section{Result And Discussion Experimental And Simulation single battery}

Results of the experiment compared with solidwork software, it aims to solidwork effectiveness of the experiment. Experiments performed with a single battery at temperatures of $45^{\circ} \mathrm{C}$ battery (charging), $50^{\circ} \mathrm{C}$ (discharging) and $60^{\circ} \mathrm{C}$ (discharging). data collection in the experiment takes the temperature at each reservation point and enters that value into the software techplot.

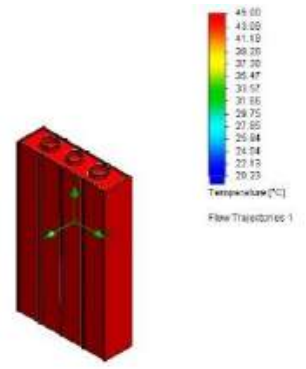

a

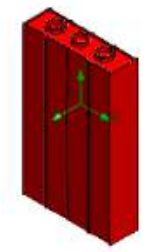

b
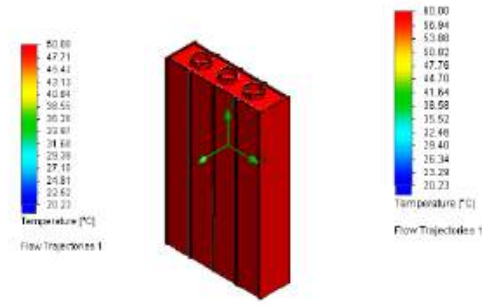

$\mathrm{c}$

Fig 4. Simulation of Solidwork software without fan (a) $45^{\circ} \mathrm{C}$, (b) $50^{\circ} \mathrm{C}$ and (c) $60^{\circ} \mathrm{C}$. 


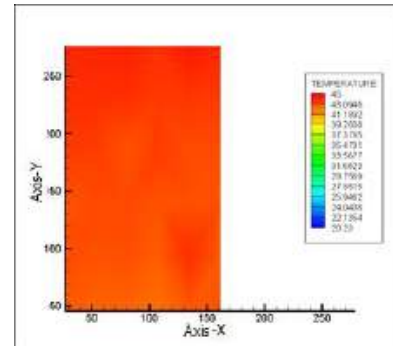

a

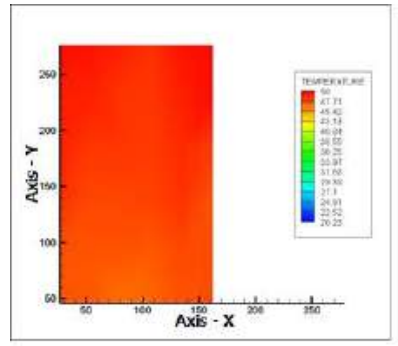

b

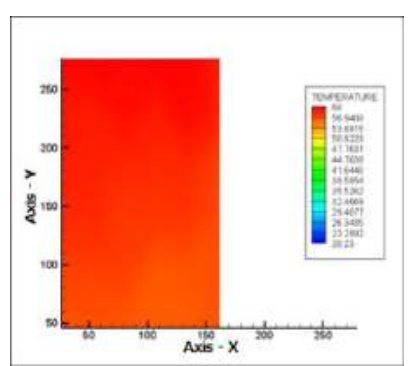

c

Fig 5. Experiment temperature with Techplot 360 without fan (a) $45^{\circ} \mathrm{C}$, (b) $50^{\circ} \mathrm{C}$ and (c) $60^{\circ} \mathrm{C}$.
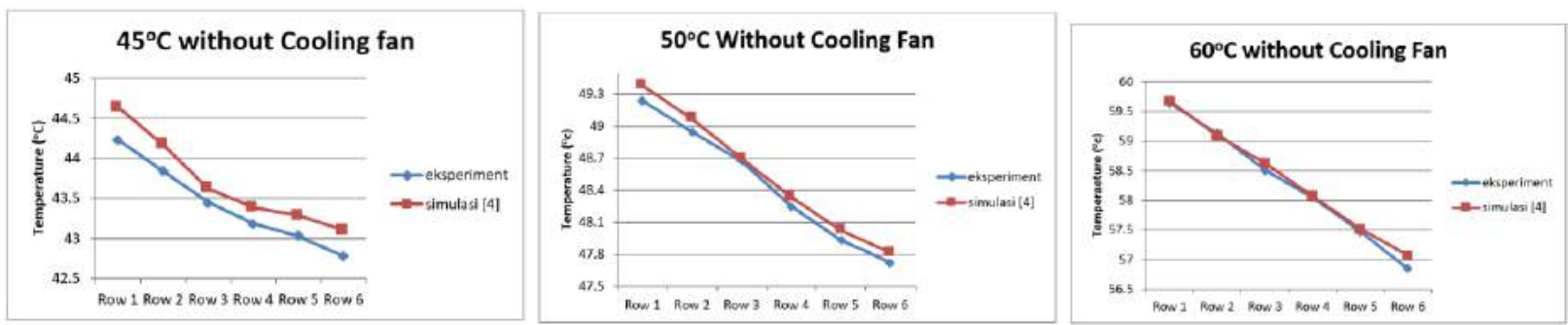

Fig 6. Comparison of experimental method with simulated temperature without cooling fan at $45^{\circ} \mathrm{C}, 50^{\circ} \mathrm{C}, 60^{\circ} \mathrm{C}$ Experiments and Simulations of Temperature With Cooling Fan.
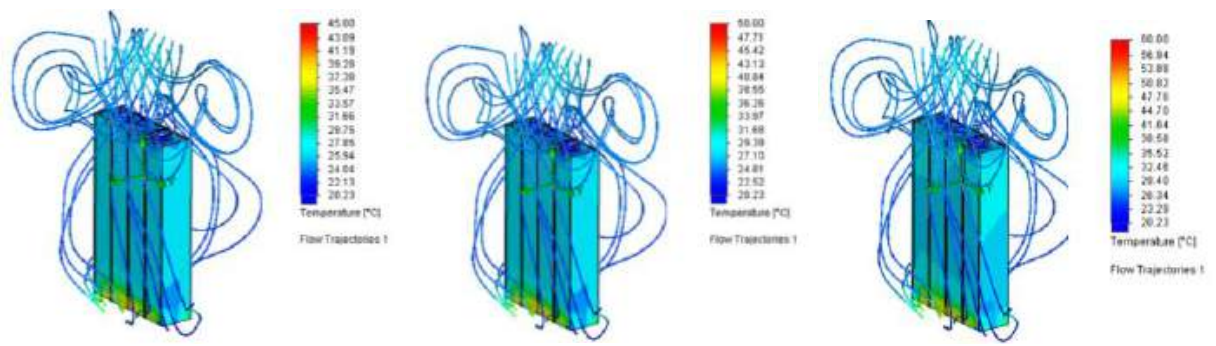

Fig 7. Simulation of Solidwork software with fan (a) $45^{\circ} \mathrm{C}$, (b) $50^{\circ} \mathrm{C}$, (c) $60^{\circ} \mathrm{C}$
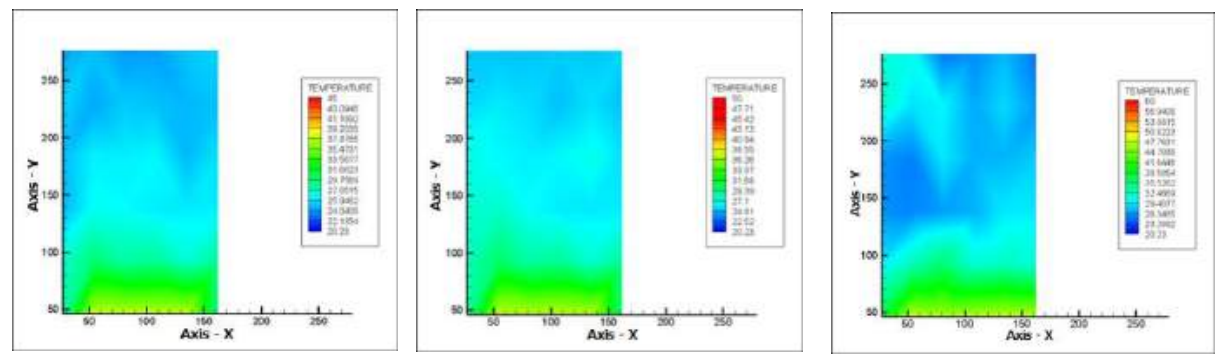

Fig 8. Experiment temperature with Techplot 360 with fan (a) $45^{\circ} \mathrm{C}$, (b) $50^{\circ} \mathrm{C}$, (c) $60^{\circ} \mathrm{C}$
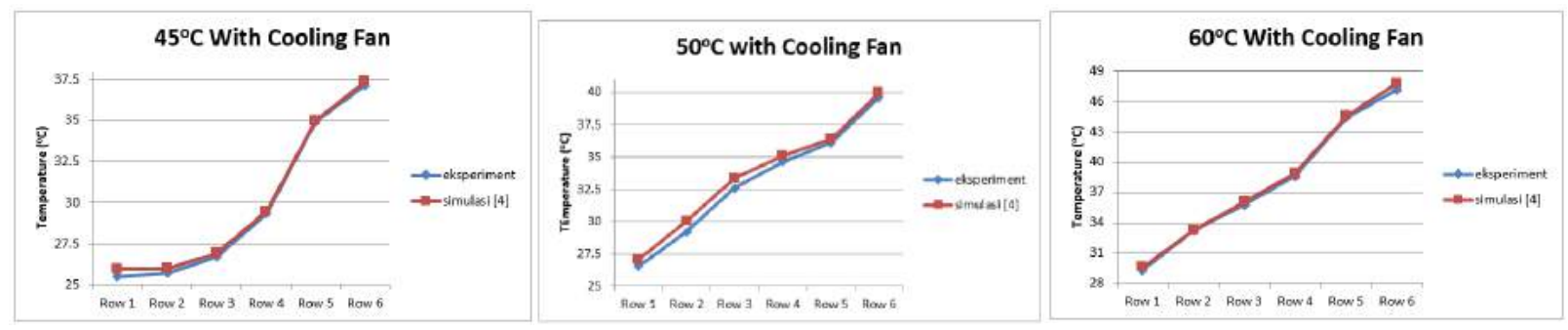

$\underline{\text { http://ijstm.inarah.co.id }}$ 
Fig 9. Comparison of experimental method with simulated temperature with cooling fan at (a) $45^{\circ} \mathrm{C}$, (b) $50^{\circ} \mathrm{C}$,

(c) $60^{\circ} \mathrm{C}$

Comparison Management Thermal at $45^{\circ} \mathrm{C}$ (charging), $50^{\circ} \mathrm{C}, 6^{\circ} \mathrm{C}$ (Discharging)

Table 2. Comparison of temperature $45^{\circ} \mathrm{C}$

\begin{tabular}{lcccr}
\hline Method & Thermal Test $\left({ }^{\circ} \mathbf{C}\right)$ & Fan Status & Temperature $\left({ }^{\circ} \mathbf{C}\right)$ & Average $\left({ }^{\circ} \mathbf{C}\right)$ \\
\hline Experiment & 45 & off & $43.09-44.94$ & 43,417 \\
Simulation & 45 & off & $43.10-45.00$ & 43,701 \\
Experiment & 45 & on & $25.00-37.68$ & 29,884 \\
Simulation & 45 & on & $25.90-37.58$ & 30,126 \\
\hline
\end{tabular}

Tabel 3. Comparison of temperature at $50^{\circ} \mathrm{C}$ (Discharging)

\begin{tabular}{lcccr}
\hline Method & Thermal Test $\left({ }^{\circ} \mathbf{C}\right)$ & Fan Status & Temperature $\left({ }^{\circ} \mathbf{C}\right)$ & Average $\left({ }^{\circ} \mathbf{C}\right)$ \\
\hline Experiment & 50 & off & $47.00-49.90$ & 48,462 \\
Simulation & 50 & off & $47.10-50.00$ & 48,555 \\
Experiment & 50 & on & $25.65-39.36$ & 33,110 \\
Simulation & 50 & on & $26.05-39.78$ & 33,635 \\
\hline
\end{tabular}

Table 4. Comparison of temperature $60^{\circ} \mathrm{C}$ (Discharging)

\begin{tabular}{lcccc}
\hline Method & Thermal Test $\left({ }^{\circ} \mathbf{C}\right)$ & Fan Status & Temperature $\left({ }^{\circ} \mathbf{C}\right)$ & Average $\left({ }^{\mathbf{0}} \mathbf{C}\right)$ \\
\hline Experiment & 60 & off & $56.23-59.80$ & 58,270896 \\
Simulation & 60 & off & $56.82-60.00$ & 58,33875 \\
Experiment & 60 & on & $28.34-47.78$ & 38,056042 \\
Simulation & 60 & on & $29.40-47.93$ & 38,336667 \\
\hline
\end{tabular}

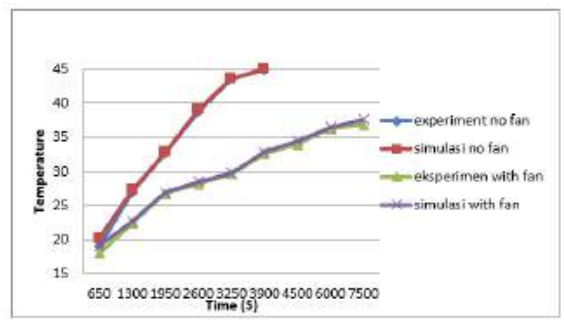

a

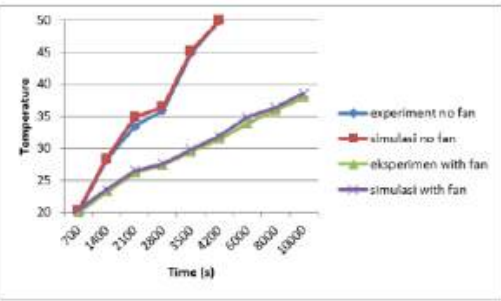

$\mathrm{b}$

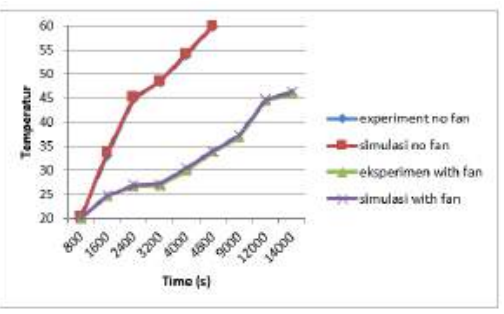

$\mathrm{c}$

Fig 10. Comparison thermal management (a) $45^{\circ} \mathrm{C}$, (b) $50^{\circ} \mathrm{C}$, (c) $60^{\circ} \mathrm{C}$

Figure 10 show the effectiveness of the cooling system at the time of charging at $45^{\circ} \mathrm{C}$. In the experiments without the cooling system, battery temperature at $45^{\circ} \mathrm{C}$ While using the cooling system, the temperature reached $37.68^{\circ} \mathrm{C}$, battery temperature up to $50^{\circ} \mathrm{C}$. While using the cooling system, the temperature reached $39.36^{\circ} \mathrm{C}$ and battery temperature up to $60^{\circ} \mathrm{C}$. While using the cooling system, the temperature reached $47.78^{\circ} \mathrm{C}$. This research was conducted to look for optimization of thermal management of the battery pack. Research carried out by solidwork software, with the difference in battery gap of $10 \mathrm{~mm}, 20 \mathrm{~mm}$ and $30 \mathrm{~mm}$, the fan speed and the number of fans.

Simulation with fan velocity $415.21384 \mathrm{rad} / \mathrm{s}$ and space $30 \mathrm{~mm}$
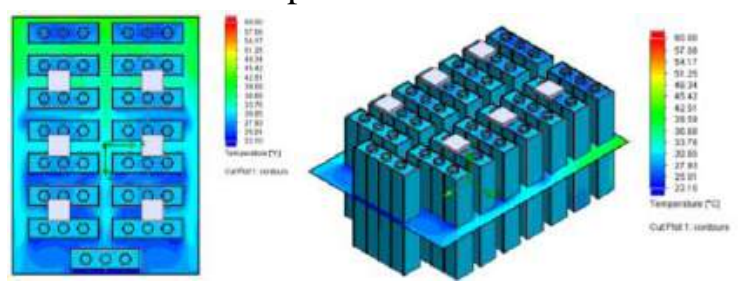

Fig 11. Simulation With 6 Fans, Battery Gap 30mm, Full Speed 
In figure 11 shows the fan cools the battery evenly, this is due to the distance $30 \mathrm{~mm}$ and the fan speed is high rpm. In the figure average temperature of the battery is $25.01-39.59^{\circ} \mathrm{C}$ Simulation with 4 cooling fan.
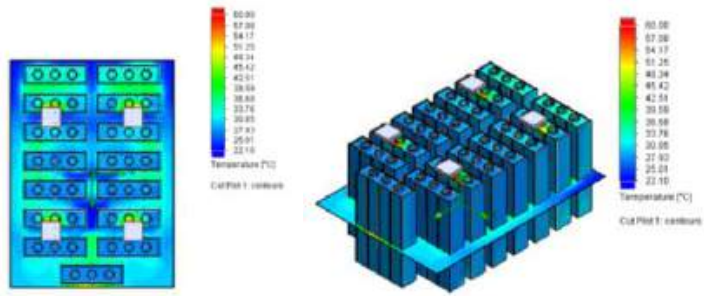

Fig 12. Simulation With 4 Fans, Battery Gap 30mm, Full Speed

In figure 12 shows the fan cools the battery evenly, this is due to the distance $30 \mathrm{~mm}$ and the fan speed is high enough. Uneven temperature distribution of the fluid so that at the edges of the higher battery temperature. This is due to the amount of fan 4 pieces with a distance of $30 \mathrm{~mm}$. In the Figure the average temperature of the battery is $29.54-43.380$ C.The picture shows the battery temperature is different, but using 6 fan fluid temperature distributions is more evenly distributed compared to 4 fans. The use of more efficient fan 6 for a distance of 30mm with fan speed $415.21384 \mathrm{rad} / \mathrm{s}$ with temperature $25.01-39.59 \mathrm{oC}$

Simulation with fan velocity $296.45129 \mathrm{rad} / \mathrm{s}$ and space $30 \mathrm{~mm}$

Simulation with 6 cooling fan.
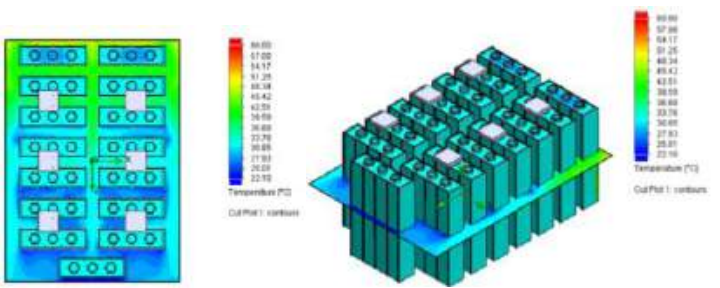

Fig 13. Simulation With 6 Fans, Battery Gap 30mm, Normal Speed

In figure 13 shows the fan cools the battery with a uniform, but the uneven distribution of the fluid temperature is visible on the edge of the battery, this is due to the distance battery $30 \mathrm{~mm}$ and low fan speed. In the Figure the average temperature of the battery is $25.01-42.51^{\circ} \mathrm{C}$

Simulation with 4 cooling fan.
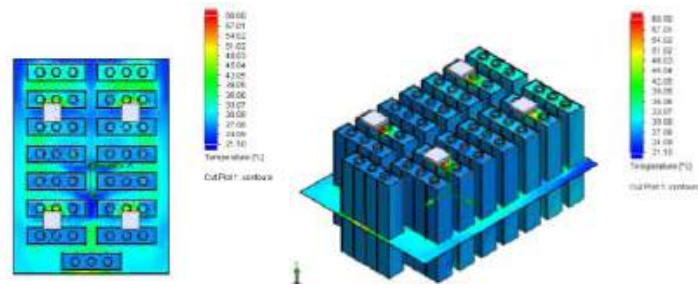

Fig 14. Simulation With 4 Fans, Battery Gap 30mm, Normal Speed

In figure 14 shows the fan cools the battery with a uniform, but the uneven distribution of the fluid temperature is seen in the center of the battery, this is due to the distance to the other battery $130 \mathrm{~mm}$ and low fan speed. In the Figure the average temperature of the battery is $29.54-43.38^{\circ} \mathrm{C}$. The picture shows the battery temperature is not much different, but using 6 fan fluid temperature distribution is more evenly distributed compared to 4 fan. The use of more efficient fan 6 for a distance of $30 \mathrm{~mm}$ with fan speed $296.45129 \mathrm{rad} / \mathrm{s}$ with temperature $25.01-42.51 \mathrm{oC}$ 


\section{Simulation with fan velocity $415.21384 \mathrm{rad} / \mathrm{s}$ and space $20 \mathrm{~mm}$}

Simulation with 6 cooling fan.
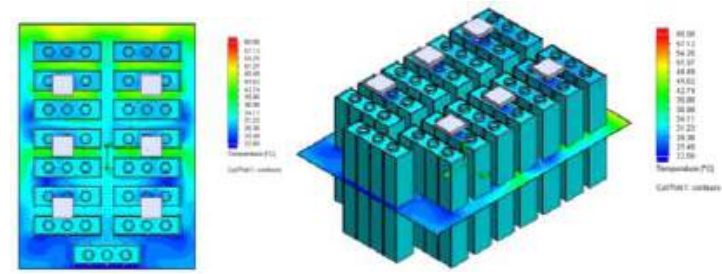

Fig 15. Simulation With 6 Fans, Battery Gap 30mm, Full Speed

In figure 15 shows the fan cools evenly battery, but the battery temperature higher than the battery space of $30 \mathrm{~mm}$, while the uneven distribution of the fluid temperature is visible on the edge of the battery. Turbulent fluid flow is experiencing is due within one another battery of $20 \mathrm{~mm}$ and high fan speeds. In the Figure the average temperature of the battery is $25.48-39.59 \mathrm{oC}$

Simulation with 4 cooling fan.
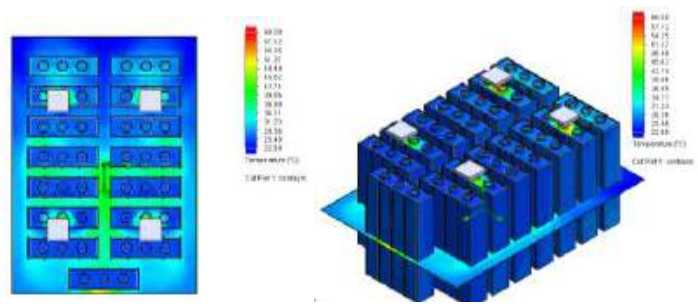

Fig 16. Simulation With 4 Fans, Battery Gap 30mm, Full Speed

In figure 16 shows the fan cools the battery with a uniform and cooler than using a 6 fan while the uneven distribution of the fluid temperature is seen in the middle and edge of the battery. The experience turbulent fluid flow smaller than 6 fan. it is due within one another battery of $20 \mathrm{~mm}$ and high fan speeds. In the Figure the average temperature of the battery is $28.36-42.74^{\circ} \mathrm{C}$.

Simulation with fan velocity $296.45129 \mathrm{rad} / \mathrm{s}$ and space $20 \mathrm{~mm}$

Simulation with 6 cooling fan
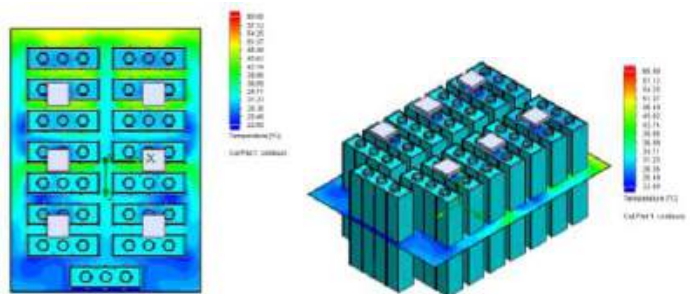

Fig 17. Simulation With 6 Fans, Battery Gap 30mm, Normal Speed

In figure 17 shows the fan cools evenly battery, but the battery temperature higher than the battery space of $30 \mathrm{~mm}$, and fan speed and uneven distribution of the fluid temperature is seen in the middle and edge of the battery. In the Figure the average temperature of the battery is $25.48-42.74{ }^{\circ} \mathrm{C}$.

Simulation with 4 cooling fan
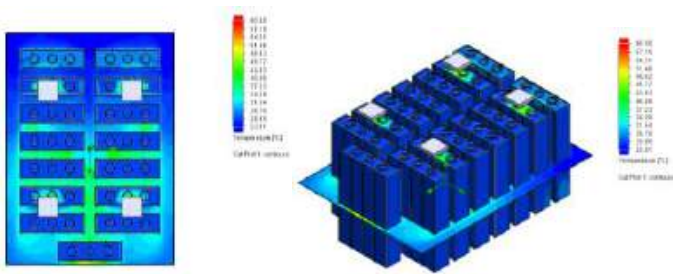

Fig 18. Simulation With 4 Fans, Battery Gap 30mm, Normal Speed 
In figure 18 shows the fan cools evenly battery, but the battery temperature higher than the battery space of $30 \mathrm{~mm}$, and fan speed and uneven distribution of the fluid temperature is seen in the middle and edge of the battery. In the figure the average temperature of the battery is $28.70-42.93{ }^{\circ} \mathrm{C}$.

\section{Simulation with fan velocity $415.21384 \mathrm{rad} / \mathrm{s}$ and space $10 \mathrm{~mm}$}

Simulation with 6 cooling fan
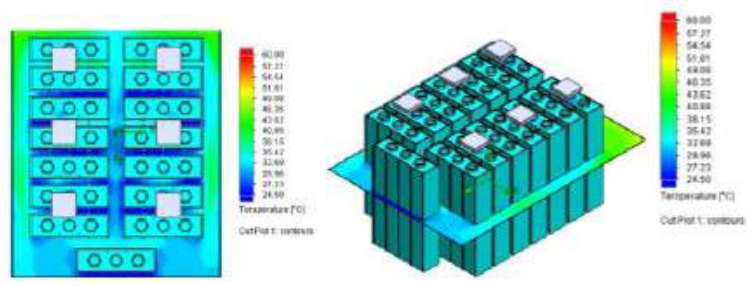

Fig 19. Simulation With 6 Fans, Battery Gap 30mm, Full Speed

In figure 19 shows the fan cools evenly battery, but the battery temperature higher than the battery space of $20 \mathrm{~mm}$, and fan speed and uneven distribution of the fluid temperature is seen in the middle and edge of the battery. In the figure the average temperature of the battery is $27.23-40.88^{\circ} \mathrm{C}$.

Simulation with 4 cooling fan
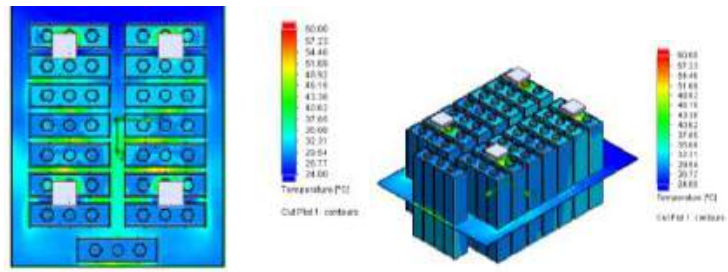

Fig 20. Simulation With 4 Fans, Battery Gap 30mm, Full Speed

In figure 20 shows the fan cools evenly battery, but the battery temperature higher than the battery space of $30 \mathrm{~mm}$, and fan speed and uneven distribution of the fluid temperature is seen in the middle and edge of the battery. In the Figure the average temperature of the battery is $31.34-43.38{ }^{\circ} \mathrm{C}$. The space simulation with battery $10 \mathrm{~mm}$ with fan speed $415.21384 \mathrm{rad} / \mathrm{s}$, the use of 4 fan more effective.

\section{Simulation with fan velocity $296.45129 \mathrm{rad} / \mathrm{s}$ and space $10 \mathrm{~mm}$}

Simulation with 6 cooling fan
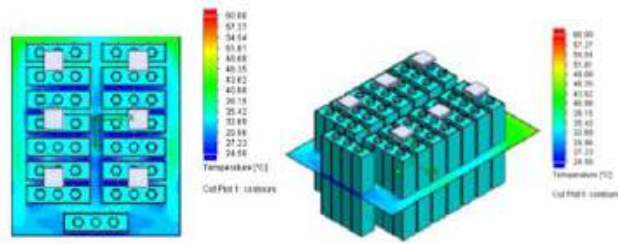

Fig 21. Simulation With 6 Fans, Battery Gap 30mm, Normal Speed

In figure 21 shows the fan cools evenly battery, but the battery temperature higher than the battery space of $20 \mathrm{~mm}$, and fan speed and uneven distribution of the fluid temperature is seen in the middle and edge of the battery. In the Figure the average temperature of the battery is $27.23-43.62{ }^{\circ} \mathrm{C}$.

Simulation with 4 cooling fan
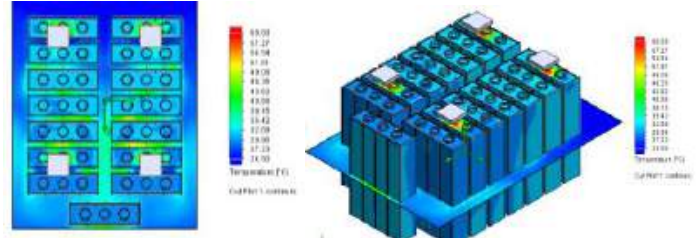

Fig 22. Simulation With 4 Fans, Battery Gap 30mm, Normal Speed 
In figure 22 shows the fan cools evenly battery, but the battery temperature higher than the battery space of $20 \mathrm{~mm}$, and fan speed and uneven distribution of the fluid temperature is seen in the middle and edge of the battery. In the figure the average temperature of the battery is $29.96-43.62 \mathrm{oC}$. In the space simulation with battery $10 \mathrm{~mm}$ with fan speed $296.45129 \mathrm{rad} / \mathrm{s}$, the use of 4 fan more effective.

\section{Comparison management thermal}

Tabel 6. Comparison management thermal with battery gap 30mm

\begin{tabular}{crcll}
\hline Battery Gap (mm) & Fan & Fan velocity rad/s & Temperature $\left({ }^{\circ} \mathbf{C}\right)$ & Average $\left({ }^{\circ} \mathbf{C}\right)$ \\
\hline 30 & 6 & 415 & $25.11-38.79$ & 32.607 \\
30 & 4 & 415 & $27.34-39.18$ & 35.309 \\
30 & 6 & 296 & $25.41-39.19$ & 33.856 \\
30 & 4 & 296 & $27.93-39.59$ & 36.959 \\
\hline
\end{tabular}

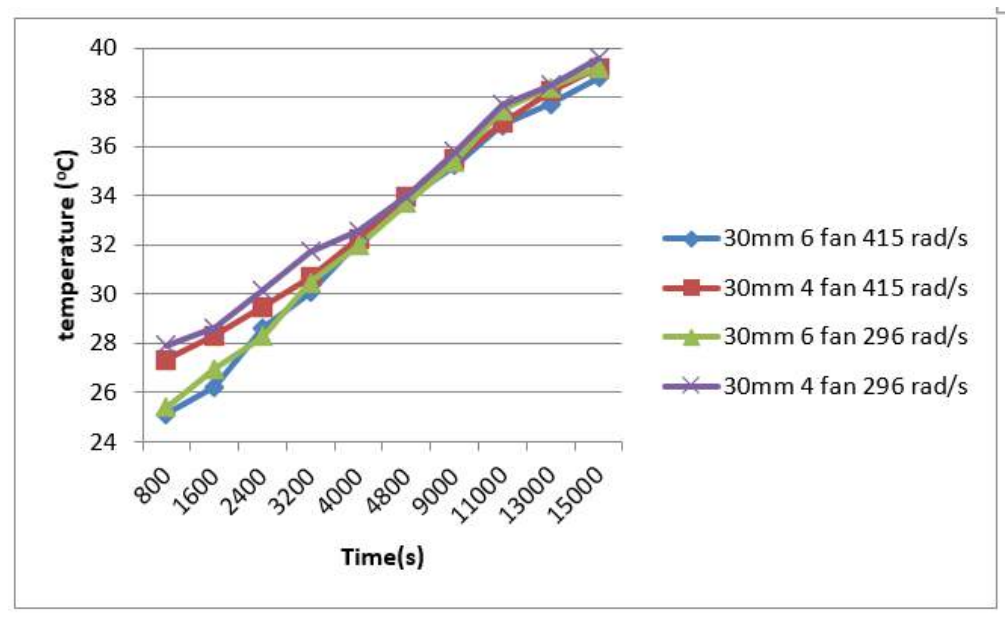

Fig 23. Comparison Management Thermal With Battery Space $30 \mathrm{~mm}$

Tabel 7. Comparison management thermal with space battery $20 \mathrm{~mm}$

\begin{tabular}{crcll}
\hline Battery Gap $(\mathbf{m m})$ & Fan & Fan velocity rad/s & Temperature $\left({ }^{\circ} \mathbf{C}\right)$ & Average $\left({ }^{\circ} \mathbf{C}\right)$ \\
\hline 20 & 6 & 415 & $25.48-39.59$ & 32.524 \\
20 & 4 & 415 & $28.36-42.74$ & 35.331 \\
20 & 6 & 296 & $25.88-42.74$ & 33.818 \\
20 & 4 & 296 & $28.70-42.93$ & 35.359 \\
\hline
\end{tabular}

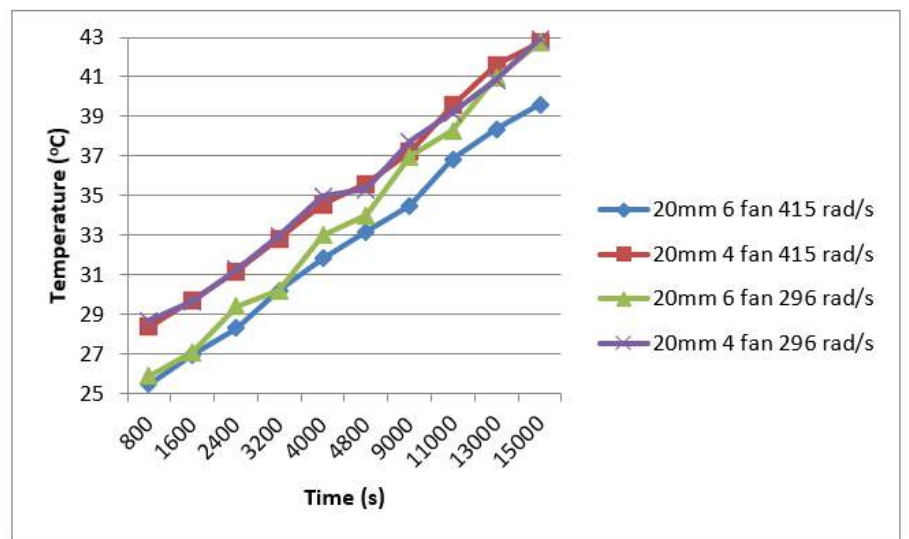

Fig 24. Comparison Management Thermal With Battery Space 20mm 
In the figure 24 visible influences the fan speed and the amount of the cooling fan, the greater number of the fan, the more cold and uneven distribution of heat transfer fluid. In the Figure 4 use the maximum speed of the fan and have the highest efficiency.

Tabel 8. Comparison management thermal with space battery $10 \mathrm{~mm}$

\begin{tabular}{crccl}
\hline Battery Gap $(\mathbf{m m})$ & Fan & Fan velocity $\mathbf{~ r a d} / \mathbf{s}$ & Temperature $\left({ }^{\mathbf{0}} \mathbf{C}\right)$ & Average $\left({ }^{\mathbf{0}} \mathbf{C}\right)$ \\
\hline 10 & 6 & 415 & $27.23-40.88$ & 33.441 \\
10 & 4 & 415 & $29.54-43.38$ & 36.224 \\
10 & 6 & 296 & $27.73-43.62$ & 35.191 \\
10 & 4 & 296 & $29.96-43.62$ & 35.110 \\
\hline
\end{tabular}

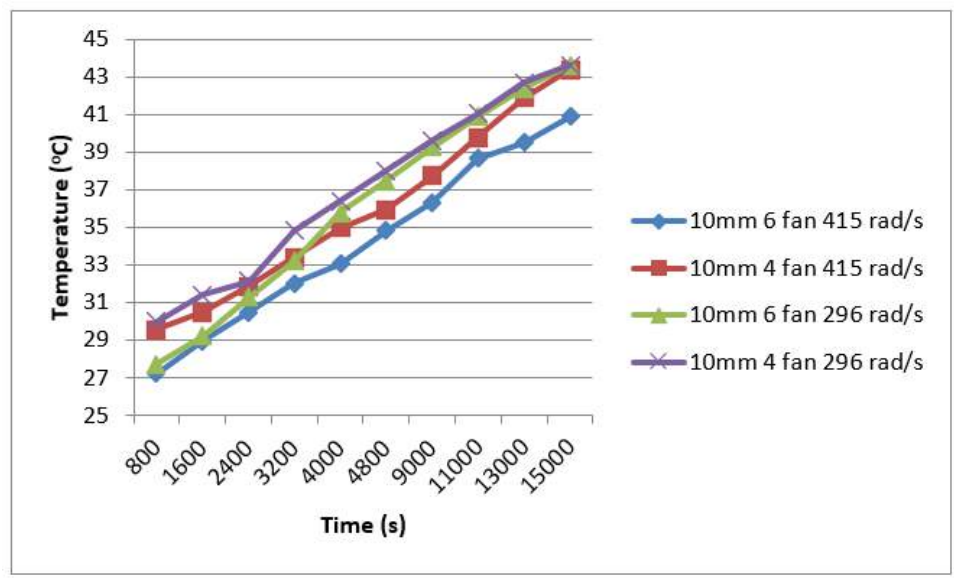

Fig 25. Comparison Management Thermal With Battery Space $10 \mathrm{~mm}$

From the figure 24 and 25 seen the influence of the fan speed, battery space and the number of cooling fans. Based on the graph that has obtained the highest level of efficiency is in the battery space and four $20 \mathrm{~mm}$ cooling fans with fan speed $415.21384 \mathrm{rad} / \mathrm{s}$. whereas the highest efficiency in the heat transfer fluid that is $30 \mathrm{~mm}$ and 6 cooling fans with fan speed $415.21384 \mathrm{rad} / \mathrm{s}$.
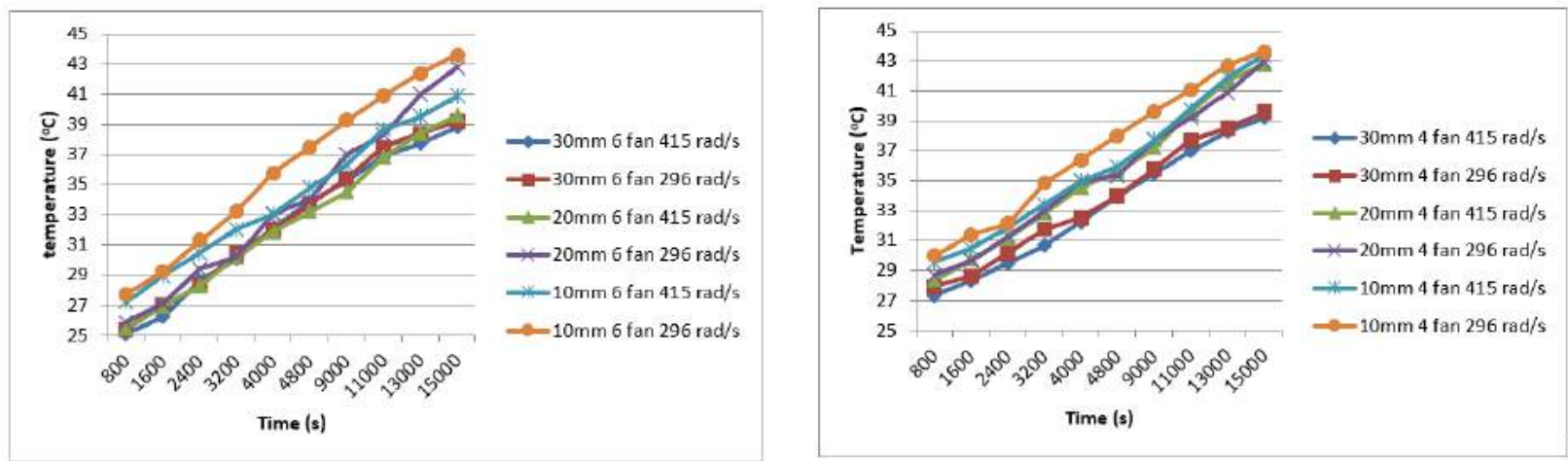

Fig 26. Comparison management thermal with 6 and 4 cooling fan

In the figure 26 show visible influence of the fan speed, battery gap and the number of cooling fans with 6 fan. Highest efficiency is $20 \mathrm{~mm}$ with 6 fan and use full speed $415.21384 \mathrm{rad} / \mathrm{s}$, whereas the lowest efficiency is $10 \mathrm{~mm}$ and 6 cooling fans with fan speed $296.45129 \mathrm{rad} / \mathrm{s}$.In the figure 26 show visible influence of the fan speed, battery gap and the number of cooling fans with 4 fan. Highest efficiency is $30 \mathrm{~mm}$ with 4 fan and use full speed $415.21384 \mathrm{rad} / \mathrm{s}$, but temperature minimum battery is highest for all with 4 cooling fan. Whereas the lowest efficiency is $10 \mathrm{~mm}$ and 6 cooling fans with fan speed $296.45129 \mathrm{rad} / \mathrm{s}$. To facilitate determining the best thermal management optimization of the ratio seen from the level of the most efficient in the use of 4 and 6 fans. 


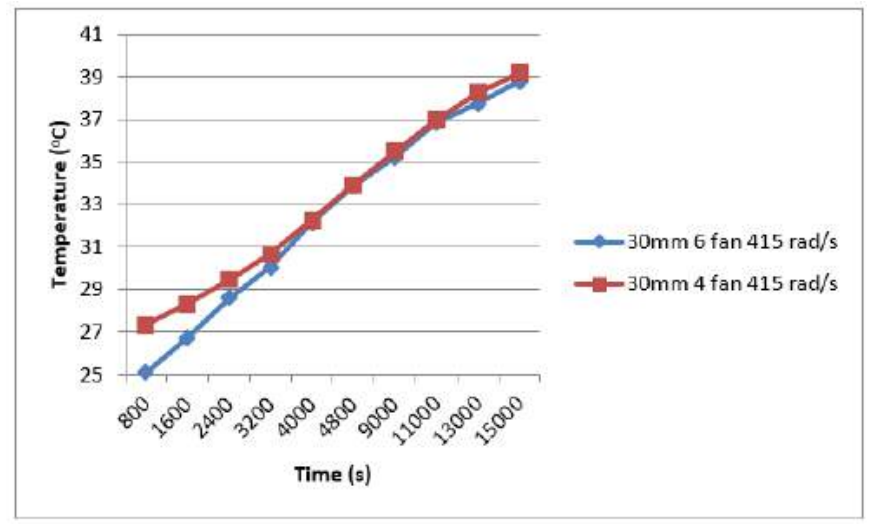

Fig 27. Comparison the most efficient management thermal with 4 and 6 fans.

In the figure 27 show difference in battery temperature. In the cooling system that uses 4 fan with battery gap 30mm, 4 fan, temperature more high than using 6 fan with battery gap 30mm. in the figure 26 . show system using 30mm and 6 fan the most efficient for all.

\section{Range Optium of Battery Temperature}

Range optimum of battery temperature is 60 with triple pack, the temperature average is 38.66. Based characteristic of LifeP04 battery, the optimum temperature range beetwen $10^{\circ} \mathrm{C} .-40^{\circ} \mathrm{C}$. The result show that range optimum of battery temperature is $60^{\circ} \mathrm{C}$ with triple pack model.

\section{The Heat Transfer Coefficient Battery Calculations}

Specification Cell Battery

Length Cells $\quad: 134.5 \mathrm{~mm}$

Diameter Cells : $33.5 \mathrm{~mm}=0.0335 \mathrm{~m}$

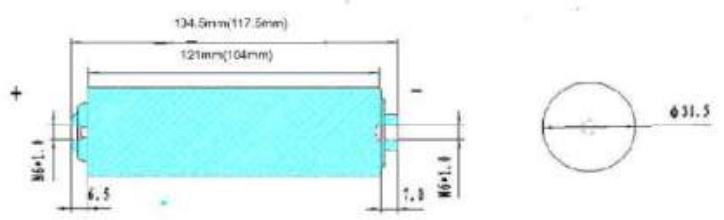

\section{The heat transfer coefficient battery $45^{\circ} \mathrm{C}$ (Charging)}

The heat transfer coefficient battery $45^{\circ} \mathrm{C}$ (Charging Position). The forced air flow (Fan) $0.039 \mathrm{~m} 3 / \mathrm{s}$.

The value of velocity fan is obtained from database SolidWorks Flow simulation (Papst 4500N).

The ratio of Reynolds number on battery can be calculated by:

$$
R_{e}=\frac{v \times D_{h}}{\mu}
$$

$\mathrm{Re}$ is the ratio of Reynolds number, $\mathrm{v}$ is the velocity of fan, $\mathrm{Dh}$ is the cell diameter, and $\mu$ is kinematic viscosity.

$$
R_{e}=\frac{v \times D_{h}}{\mu}=\frac{0.039 \mathrm{~m}^{3} / \mathrm{s} \times 0.0335 \mathrm{~m}}{17,45 \times 10^{-6} \mathrm{~m}^{2} / \mathrm{s}}=74,87
$$

The result show that the value of $\operatorname{Re}$ is 74,87 , this value is laminar type of flow. The Nusselt number can be calculated after completed calculations of Reynolds number. Prandtl Numbers be obtained from the table properties of air, Value of $\operatorname{Pr} 0.7105$. The Nusselt number on battery can be calculated by :

$$
N_{u}=0,023 \operatorname{Re}^{0.8} \operatorname{Pr}^{0.3}=(0.023 \times 74,87)^{0.8} \times 0,7105^{0.3}=1,394
$$

$\mathrm{Nu}$ is the Nusselt number, Re is the Reynolds number, and Pr is the Prandtl Numbers. 
The result show that the value of $\mathrm{Nu}$ is 1,394 with thermal conductivity $0.278 \mathrm{~W} / \mathrm{m} .{ }^{\circ} \mathrm{C}$. The heat transfer coefficient can be calculated by:

$$
h=\frac{k}{D} N_{u}=\frac{0.0278 \mathrm{~W} / \mathrm{m}^{\circ} \mathrm{K}}{0.0335 \mathrm{~m}} \times 1,394=1.157 \mathrm{~W} / \mathrm{m}^{2} . \mathrm{K}
$$

Where $\mathrm{h}$ is heat transfer coefficient, $\mathrm{k}$ is thermal conductivity of air, $\mathrm{D}$ is the cell diameter, $\mathrm{Nu}$ is the Nusselt number. The result show that the value of convection coefficient is $1.157 \mathrm{~W} / \mathrm{m} 2 . \mathrm{K}$.

Total of convection coefficient on cells in the battery is:

$$
1,157 \mathrm{~W} / \mathrm{m}^{2} . \mathrm{K} \times 8 \text { cells }=9.256 \mathrm{~W} / \mathrm{m}^{2} . \mathrm{K}
$$

Total of convection coefficient on configuration battery pack is :

$$
9.256 \mathrm{~W} / \mathrm{m}^{2} . \mathrm{K} \times 45 \text { unit }=416.52 \mathrm{~W} / \mathrm{m}^{2} . \mathrm{K}
$$

\section{CONCLUSION}

Cooling management system of LiFePO4 battery pack for hybrid electrical vehicle application has been done successfully. This is done using battery gap 10mm, 20mm and 30mm, 4 and 6 fans and differences velocity fan.At the comparison experimental and simulation give result, which is cooling system is done by simulation more heat than experiment in the amount of $0.02 \%$. The cooling system in battery pack for 4 fans, battery gap $30 \mathrm{~mm}$ is the most efficient compared to other 4 fans. While cooling system in the battery pack for 6 fans, battery gap $30 \mathrm{~mm}$ is the most efficient to all.

\section{REFERENCES}

[1] Zhang, Yan-Tao, et al. "Develop of a fuel consumption model for hybrid vehicles." Energy Conversion and Management 207.2020

[2] Lefebvre, Ludovic. "Smart Battery Thermal Management for PHEV Efficiency." Oil \& Gas Science and Technology-Revue d'IFP Energies Nouvelles".2013.

[3] Lundgren, Henrik, et al. "Thermal management of large-format prismatic lithium-ion battery in PHEV application." Journal of The Electrochemical Society. 2015

[4] Yuksel, Tugce, and Jeremy J. Michalek. "Evaluation of the effects of thermal management on battery life in plug-in hybrid electric vehicles".2012

[5] Fisk, Heidi, and Johan Leijgård. A Battery Management Unit. MS thesis. 2010.

[6] An, Zhoujian, et al. "A review on lithium-ion power battery thermal management technologies and thermal safety." Journal of Thermal Science 2017

[7] Andersson, Peter, and Olle Collin."Parameterization of a 14.5 Ah LiFePO4-battery cell".2009

[8] Linden, David and Reddy, Thomas.Handbook of batteries. McGraw-Hill, New York.2002 